\title{
Sprawozdanie z 32. Międzynarodowego Zjazdu Europejskiego Towarzystwa Regionalnej Anestezji i Leczenia Bólu w Glasgow w 2013 roku
}

W dniach 4-7 września 2013 roku uczestniczyłem w 32. Międzynarodowym Zjeździe Europejskiego Towarzystwa Regionalnej Anestezji i Leczenia Bólu (European Society of Regional Anesthesia \& Pain Therapy, ESRA). Ceremonia otwarcia Zjazdu odbyła w audytorium położonym nad rzeką Clyde w Glasgow, natomiast obrady prowadzone były w Centrum Konferencyjnym (Scotish Exhibition and Conference Centre). W tym roku ESRA obchodziło ponad trzydzieści lat swego istnienia, ponieważ zostało utworzone w 1982 roku. Obecnie przewodniczącym ESRA jest Marc van de Velde z Belgii, a aktualna liczba członków to ponad 2900 lekarzy. Dominują wśród nich lekarze z Anglii, Francji i Belgii. W tym roku w Zjeździe uczestniczyło ponad 1500 uczestników z 62 krajów, w tym również z Polski.

W ciągu 4 dni odbyło się 8 sesji tematycznych, które dotyczyły leczenia ostrego i przewlekłego bólu pooperacyjnego, centralnych i obwodowych blokad nerwów, znieczulenia regionalnego w położnictwie i pediatrii oraz zastosowania ultrasonografii w znieczuleniach regionalnych.

Z uwagi na posiadaną przeze mnie specjalność chirurga onkologicznego skupiłem swoją uwagę na sesjach poświęconych zagadnieniom ostrego i przewlekłego bólu pooperacyjnego oraz na tematyce dotyczącej wpływu różnych typów znieczuleń na ryzyko wznowy choroby nowotworowej. Do grupy tematycznej poświęconej ostremu bólowi pooperacyjnemu została zakwalifikowana praca z naszej kliniki dotycząca bólu u chorych po mastektomii, która powstała przy współudziale Kliniki Anestezjologii i Intensywnej Terapii GUMed, kierowanej przez prof. Marię Wujtewicz. Uzyskane przez nas korzystne wyniki leczenia bólu u chorych po mastektomii stały się standardem leczenia w naszej Klinice stosownie do ogólnych trendów multimodalnego leczenia ostrego bólu pooperacyjnego.
Bardzo interesujący oraz ważny wykład dotyczący wpływu rodzaju znieczulenia na ryzyko wznowy nowotworowej zaprezentował prof. Antje Gottschalk z Niemiec. Z prezentacji wynikało, że czynnikami zapobiegającymi wznowie raka są: użycie propofolu, wszystkie procedury zmniejszające użycie opioidów (takie jak: znieczulenie miejscowe, NSAID), użycie beta-blokerów oraz statyn. Profesor Gottschalk przedstawił ciekawą hipotezę, która potwierdzona została w badaniach doświadczalnych, że ostry pooperacyjny ból może wyzwalać mediatory pobudzające rozwój raka i jest ważnym czynnikiem ryzyka wznowy choroby nowotworowej. Ponadto dodatkowymi czynnikami podwyższającymi ryzyko wznowy raka są: hipotermia, hipotensja oraz anemia.

Na uwagę zasługuje wzrastająca rola ultrasonografii $w$ regionalnej anestezji. Temu zagadnieniu poświecono wiele prezentacji, szczególnie w odniesieniu do znieczulenia do zabiegów operacyjnych i leczenia bólu przewlekłego w postaci blokad w zakresie kończyn górnych lub dolnych. Wyrazem znacznego zainteresowania tym zagadnieniem była duża liczba firm prezentujących nowe urządzenia zapatrzone w systemy nawigacji, umożliwiające bardziej precyzyjne docieranie do znieczulanych nerwów.

Podsumowując, powyższy Zjazd był ciekawym wydarzeniem dla lekarzy różnych specjalności i stanowi potwierdzenie, że w obecnej medycynie konieczna jest interdyscyplinarna współpraca, która służy podniesieniu jakości życia leczonych chorych. W związku z tym gorąco polecam kolejny Zjazd organizowany przez ERSA, planowany w Hiszpanii we wrześniu 2014 roku. Szczegółowe informacje można znaleźć pod adresem: www.kenes.com/esra.

Dr hab. n. med. Jacek Zieliński

Klinika Chirurgii Onkologicznej

Gdański Uniwersytet Medyczny

e-mail:jaziel@gumed.edu.pl 